\title{
Stable isotope compositions of bivalve shells and geochemistry of bulk sediments in a 5-20 ky fluvial section at Körösladány, SE Hungary: Sedimentary changes vs. climate signals
}

\author{
Attila Demény, Gabriella Schöll-Barna \\ Institute for Geological and Geochemical Research \\ Research Centre for Astronomy and Earth Sciences \\ Hungarian Academy of Sciences, Budapest
}

\author{
Pál Sümegi \\ Department of Geology and Palaeontology, \\ University of Szeged, Szeged
}

Péter Sipos, István Fórizs, Brigitta Réka Balázs, Bernadett Bajnóczi Institute for Geological and Geochemical Research, Research Centre for Astronomy and Earth Sciences, Hungarian Academy of Sciences. Budapest

\section{Gordon Cook}

Scottish Universities Environmental Research Centre, Glasgow

\begin{abstract}
In this paper we present sedimentological and geochemical data for a section of fluvial deposits from SE Hungary covering the period from about 20 to $5 \mathrm{ky} \mathrm{BP}$. Major and trace element geochemistry of bulk sediments as well as stable $\mathrm{C}$ and $\mathrm{O}$ isotope compositions of the carbonate content indicate significant changes in depositional facies and/or sediment provenance as well as climate conditions. Variations in bulk sediment $\mathrm{Sr}, \mathrm{TiO}_{2}$ and $\mathrm{P}_{2} \mathrm{O}_{5}$ concentrations were correlated with major climate change events following the Late Glacial Maximum that support the age model established on the basis of AMS ${ }^{14} \mathrm{C}$ age data. Bulk sediment $\mathrm{Sr}$ concentrations and stable $\mathrm{C}$ and $\mathrm{O}$ isotope compositions of bulk sediment carbonate were determined by changes in denudation of carbonate rocks in the recharge area. The $\mathrm{Sr}$ and $\mathrm{C}-\mathrm{O}$ isotope patterns show correlations with global temperature changes during the Pleistocene-Holocene transition. However, $\mathrm{TiO}_{2}$ and $\mathrm{P}_{2} \mathrm{O}_{5}$ contents show correspondence with humidity changes, suggesting variations in chemical weathering. In addition to the sedimentological effects, $\mathrm{C}$ and $\mathrm{O}$ isotope compositions of Unio crassus shell fragments show strong changes at the Pleistocene-Holocene transition, indicating that the bivalve shells can reflect climate conditions. On the other hand, shorter climate change events were difficult to track in the isotope records due to the competing fractionation processes. The combined evaluation of chemical and isotopic compositions revealed that beside the globally important Younger Dryas and Bølling/Allerød periods, the Ságvár-Lascaux interstadial was of local importance, in accordance with earlier studies.
\end{abstract}

Key words: Pleistocene-Holocene transition, Late Glacial, stable isotopes, geochemistry, fluvial sediments, Unio crassus, Sphaerium rivicola

Addresses: A. Demény, G. Schöll-Barna, P. Sipos, I. Fórizs, B. R. Balázs, B. Bajnóczi: H-1112 Budapet, Budaörsi út 45, Hungary, e-mail: demeny@geochem.hu, P. Sümegi: H-6722 Szeged, Egyetem u. 2, Hungary G. Cook: Rankine Avenue, Scottish Enterprise Technology Park, East Kilbride, Glasgow G75 0QF, Scotland, UK

Received: February 8, 2013; accepted: April 16, 2013 


\section{Introduction}

Quaternary climate change events have been well documented in ice core (e.g. Petit et al. 1999; EPICA community members 2004) and deep sea carbonate sediment stable isotope records (Imbrie et al. 1984). Large-scale changes (10 to 100 thousand years $[\mathrm{ky}]$ ) are attributed to variations in the Earth's orbital parameters (see EPICA community members 2004, as a comprehensive study), whereas climate fluctuations on the millennial to decadal scale are interpreted as results of a complex interplay of insolation, greenhouse gas concentration, ocean water circulation and hydrosphere-atmosphere interactions (e.g. Bond et al. 1999, 2001; Paillard 2001; Versteegh 2005; Schulz and Zeebe 2006; Denton et al. 2010; Hurrell and Deser 2010; Morley et al. 2011). Beside marine and ice core sections, terrestrial deposits can also provide useful information on paleoclimate conditions. Loess sections have been successfully used to detect and correlate climate change events in the last $100 \mathrm{ky}$ in Europe (Shi et al. 2003). Within this period, the last 20 $\mathrm{ky}$ is of special significance, as maximum glaciation as well as warming to the present interglacial are included. Several climate fluctuation events have been distinguished within this period, including sudden cooling events (Heinrich Stadial [H1] and Younger Dryas [YD]), and relatively warm periods like the Bølling/Allerød. The Holocene warming began after the Younger Dryas period at 11700 years cal BP. These climate fluctuation events can be globally detected and correlated (Shakun and Carlson 2010). A number of studies have dealt with late glacial climate change events in the Carpathians and the Carpathian Basin on the basis of age dating, sedimentological, paleobiological and geochemical analyses conducted on loess sequences and lake deposits (e.g. Sümegi and Hertelendi 1998; Sümegi and Krolopp 2002; Feurdean et al. 2008; Novothny et al. 2009; 2011; Sümegi et al. 2011a; Schatz et al. 2011, 2012; Buczkó et al. 2012; Magyari et al. 2012a; Tóth et al. 2012). Although the results of the different paleoenvironmental reconstructions are sometimes conflicting, climate variations characterized by alternations of colder and warmer, arid and humid or windy and less windy conditions have been determined within the period of 12-80 ky BP (Sümegi and Rudner 2001; Schatz et al. 2011; Stevens et al. 2011). Speleothems that provide globally and regionally important paleoclimate data are absent from the list of late glacial paleoclimate records of the Carpathian region as stalagmite formation generally ceased in this period, due to the cold and dry climate (Siklósy et al. 2011).

A number of studies have established temperature and humidity changes in the late glacial period. The temperature change related to the PleistoceneHolocene transition was at least $4.9^{\circ} \mathrm{C}$ in terms of global mean, whereas the rise in annual mean temperature within the Carpathian Basin reached about $8-10^{\circ} \mathrm{C}$ on the basis of malacothermometry (Sümegi and Krolopp 2002), noble gas thermometric groundwater analyses (Varsányi et al. 2011) and stable oxygen isotope compositions of fossil teeth (Kovács et al. 2012). Using fossil chironomid species analyses on lake sediments from the Southern Carpathians, Tóth et al. 
(2012) determined mean July air temperature variations for the latest glacial and the Pleistocene-Holocene transition. They obtained an $\sim 8^{\circ} \mathrm{C}$ rise from the glacial maximum to the Holocene, with the Younger Dryas event showing only a slight $\left(<1^{\circ} \mathrm{C}\right)$ decrease. Since the Younger Dryas is thought to represent strong cooling in the northern hemisphere (Shakun and Carlson 2010), Tóth et al. (2012) interpreted this discrepancy as a sign of increased seasonality with very cold winters.

Beside temperature, another important climate factor is humidity, i.e. precipitation amount. Not only the mean annual precipitation, but also precipitation seasonality can be determined on the basis of paleobiological proxies and lake level estimations, as exemplified by a number of studies conducted in the Carpathian region (e.g. Tullner and Cserny 2003; Jenei et al. 2007; Sümegi et al. 2011b; Magyari et al. 2009, 2012a). Recent studies have shown that even the variations in precipitation origin, i.e. whether the moisture derived from Atlantic or Mediterranean transport trajectories, can be determined on the basis of stable isotope analyses of lake sediments and speleothems (Demény et al. 2012; Magyari et al. 2012b).

Beside the proxies described above, a further possibility to study climate conditions in the warm season is provided by freshwater bivalve shells, whose stable isotope compositions indicate temperature and humidity variations (SchöllBarna et al. 2012 and references therein). For Lake Balaton the climate - shell composition relationship is well established (Schöll-Barna et al. 2012), while the fluvial environments of the Carpathian Basin have not been studied. The aim of the present study was to determine how a major climate change event, the Pleistocene-Holocene transition, is reflected by Unio shell isotope compositions, and how the smaller-scale fluctuations in the late glacial period can be traced by these data. A 5.2 m-thick fluvial section was studied in this work to detect climate signals during the late Pleistocene and early Holocene. The sedimentary section was cleaned and collected for paleontological, geologic and geochemical analyses in the clay quarry which is located at the edge of the village of Körösladány in the southeastern part of the Great Hungarian Plain (Hungary) (Fig. 1). Based on preliminary ${ }^{14} \mathrm{C}$ age dating it was suspected that the section would cover the last approx. $20 \mathrm{ky}$. Sampling the section at $20-25 \mathrm{~cm}$ intervals was conducted, which would thus allow paleoclimate analyses at a millennial age resolution for the study of the main fluctuation processes. Unfortunately the section has been destroyed by the use of the quarry material prohibiting further, higher-resolution studies; thus this paper serves as an archive of available data. Apart from the shell analyses, geochemical analyses of bulk sediment samples were also conducted to determine erosion processes. Additional AMS (Accelerator Mass Spectrometry) ${ }^{14} \mathrm{C}$ age dating on seven shell samples supplemented the age dataset in order to establish a more reliable age-depth model that was thus based on 10 ages from the $\sim 5$ m-thick section. 


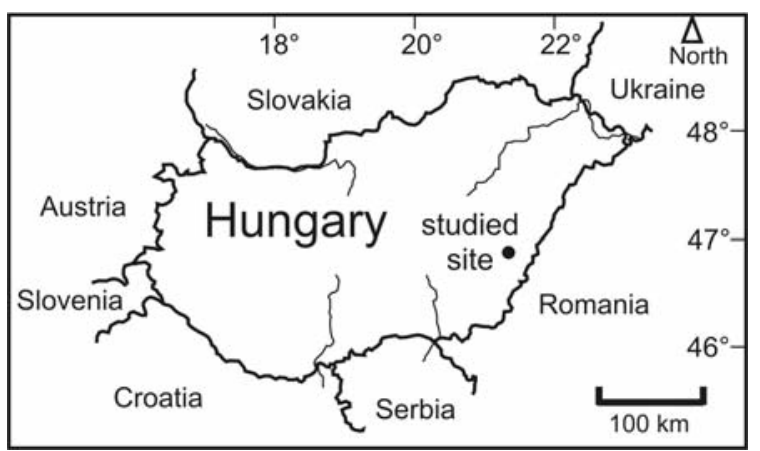

\section{Analytical methods}

Grain-size analysis followed the Casagrande-type hydrometric method (Vendel 1959). Lithostratigraphic and lithofaciological description of the sections were carried out according to the system of Troels-Smith (1955) and Bridge (1993). Radiocarbon dating was performed on mussel shells recovered from the section. As a part of a pilot study, conventional ${ }^{14} \mathrm{C}$ analyses were carried out at the Poznan Radiocarbon Laboratory, the Light Isotope Laboratory of the Nuclear Research Center of the Hungarian Academy of Sciences, and the Gliwice Radiocarbon Laboratory (one age analysis at each laboratory, samples at 100, 225 and $520 \mathrm{~cm}$ ). Subsequently new accelerator mass spectrometry (AMS) age dating was conducted for this study at the Scottish Universities Environmental Research Centre (SUERC, seven samples distributed throughout the section; see Table 2) to supplement the earlier data and to obtain a more reliable age-depth relationship. The preparation of the samples and the actual steps of the measurement followed the methods of Hertelendi et al. $(1989,1992)$. Measurements at the SUERC were conducted using a single-stage accelerator mass spectrometer (Freeman et al. 2010) and radiocarbon ages were calculated using the background subtraction method. Subsequently, all the radiocarbon dates were calibrated using the University of Oxford Radiocarbon Accelerator Unit calibration program (OxCal4). The original dates are indicated as $\mathrm{yr} \mathrm{BP}$, whereas the calibrated dates are indicated as cal BP years.

All of the following mineralogical and geochemical analyses were conducted at the Institute for Geological and Geochemical Research, Budapest. Bulk sediment samples were milled in an agate mortar to fine powder $(<50 \mu \mathrm{m})$, followed by analyses of mineralogical compositions by X-ray diffractometry (Philips PW 1730 type diffractometer). Trace element contents were determined on powder tablets using a Philips $1410 \mathrm{X}$-ray fluorescence spectrometer.

Fragments (usually $2-3 \mathrm{~cm}$ in size) of Unio crassus and Sphaerium rivicola shells were collected from the sediments at $20-25 \mathrm{~cm}$ intervals and the preservation of their original aragonite structure was checked by cathodoluminescence 
microscopy, applying a Reliotron-type cold-cathode equipment attached to a Nikon Eclipse E600 optical microscope with a Nikon Coolpix 4500 digital camera.

Carbon and oxygen isotope compositions of bulk sediment carbonate were determined using the conventional $\mathrm{H}_{3} \mathrm{PO}_{4}$ digestion method at $25{ }^{\circ} \mathrm{C}(\mathrm{McCrea}$ 1950), but applying a 2-day reaction time due to the dolomite content. The ${ }^{13} \mathrm{C} /{ }^{12} \mathrm{C}$ and ${ }^{18} \mathrm{O} /{ }^{16} \mathrm{O}$ ratios of $\mathrm{CO}_{2}$ generated were measured with a Finnigan MAT delta $\mathrm{S}$ mass spectrometer. Bivalve shells were sampled on their outer surface by using a 1-mm drill bit, collecting carbonate powder at three drilling points for each shell fragment. Batches of $0.1-0.2 \mathrm{mg}$ of carbonate were analyzed using an automated GASBENCH attached to a Finnigan Thermo delta plus XP mass spectrometer (see Spötl and Vennemann 2003); thereafter the average values for individual fragments were calculated and used in this study. Standardization was conducted using laboratory calcite standards calibrated against the NBS-19 standard. The results are expressed in the $\delta$-notation in \%o relative V-PDB $\left[\delta=\left(\mathrm{R}_{1} / \mathrm{R}_{2}-1\right) \times 1000\right]$ where $R_{1}$ is the ${ }^{13} \mathrm{C} /{ }^{12} \mathrm{C}$ or ${ }^{18} \mathrm{O} /{ }^{16} \mathrm{O}$ ratio in the sample and $\mathrm{R} 2$ the corresponding ratio of the standard. Reproducibility for both was better than $\pm 0.15 \%$.

\section{Results}

\section{Sedimentology}

According to the sedimentological, geomorphological and geofaciological investigations, the analyzed section (summarized in Table 1) consists of the sediments of a filled-up point bar channel.

The basal sediment layer consists of fluvial very fine, fine and medium-grained sand; at the center of the paleo-point bar channel the basal sandy material contains significant amounts of mussel (Unio) fragments and iron-hydroxide spots and noodles $(550-480 \mathrm{~cm})$. At the top of the basal fluvial layer a silt-rich,

Table 1

Lithological and layer changes in the analysed profile of the brickyard at Körösladány

\begin{tabular}{|c|c|c|c|c|}
\hline $\begin{array}{l}\text { Depth } \\
(\mathbf{c m})\end{array}$ & $\begin{array}{c}\text { Troels- } \\
\text { Smith } \\
\text { description }\end{array}$ & $\begin{array}{l}\text { Primary layers } \\
\text { structure }\end{array}$ & $\begin{array}{l}\text { Secondary layers } \\
\text { structure }\end{array}$ & Description \\
\hline $280-0$ & Ag2As1Lc1 & $\begin{array}{l}\text { Fine parallel } \\
\text { laminated }\end{array}$ & $\begin{array}{l}\text { Iron hydroxide and } \\
\text { carbonate noodles - spots }\end{array}$ & $\begin{array}{c}\text { Fine alluvial } \\
\text { sediment within } \\
\text { eolian dust (infusion } \\
\text { loess) }\end{array}$ \\
\hline $300-280$ & $\mathrm{Ga} 4$ & Cross-bedding & - & \multirow{5}{*}{$\begin{array}{l}\text { Active fluvial layer } \\
\text { within the cyclically } \\
\text { sedimentological } \\
\text { content changes }\end{array}$} \\
\hline $330-300$ & Gs1Ga3 & Wavy laminated & - & \\
\hline $400-330$ & $\mathrm{Ga} 4$ & Cross-bedding & - & \\
\hline $420-400$ & Gs1Ga3 & Wavy laminated & $\begin{array}{l}\text { Iron hydroxide noodles - } \\
\text { spots }\end{array}$ & \\
\hline $450-420$ & $\mathrm{Ga} 4$ & Cross-bedding & - & \\
\hline $480-450$ & $\mathrm{As} 2 \mathrm{Ag} 2$ & $\begin{array}{c}\text { Fine parallel } \\
\text { laminated }\end{array}$ & - & $\begin{array}{c}\text { Fine alluvial } \\
\text { sediment layer }\end{array}$ \\
\hline $550-480$ & Gs1Ga3 & Cross-bedding & $\begin{array}{l}\text { Iron hydroxide noodles - } \\
\text { spots }\end{array}$ & $\begin{array}{l}\text { Mussel rich sandy } \\
\text { fluvial layer }\end{array}$ \\
\hline
\end{tabular}


parallel-laminated alluvial layer formed $(480-450 \mathrm{~cm})$, which suggests that the transportation energy of the analyzed river declined. The next unit consists of different sandy layers $(450-280 \mathrm{~cm})$. Grain-size compositions, together with the sedimentary features and macrostructure, indicate cyclically-decreasing and increasing flood intensity in this period. The coarser sandy and wavy laminated layers $(420-400 \mathrm{~cm}, 330-300 \mathrm{~cm})$ suggest that the accumulation energy increased in the point bar channel, while the finer sandy and cross-bedding laminated ones $(450-420 \mathrm{~cm}, 400-330 \mathrm{~cm}, 280-300 \mathrm{~cm}$ ) formed under lower accumulation energy conditions. This cyclic sedimentation change suggests that the energy of the river and flood intensity changed gradually in this period for either tectonic and/or climatic reasons. At the top of this fluvial sediment sequence an infusion loesslike, silt-rich alluvial sediment layer formed within carbonate and iron-hydroxide noodles and spots. The development of this layer indicates that the active river phase ended in this region and alluvial deposits accumulated in the point-bar channel system. The presence of some terrestrial warmth-loving mollusk species, such as Cepaea vindobonensis, Chondrula tridens, and Granaria frumentum, suggest that this alluvial sedimentation developed in the postglacial phase, during the Early Holocene. Finally, the uppermost $50 \mathrm{~cm}$ is disturbed by anthropogenic influence, and soil formation is above $80 \mathrm{~cm}$. Although the effect of soil formation does not necessarily affect the chemical compositions of the sediment, it is indeed detected in the preservation of Unio shells that are calcitized to different degrees in the uppermost part of the section. However, based on cathodoluminescence microscopic analyses, pure aragonite is preserved in the shells at and below $80 \mathrm{~cm}$.

\section{Geochemistry}

Age-depth model calculations were carried out using the StalAge algorithm of Scholz and Hoffmann (2011) based on selected age dates (see Table 2 and Fig. 2). Ages at 150 and $475 \mathrm{~cm}$ depths were not in stratigraphic order, whereas the age obtained at $275 \mathrm{~cm}$ is an outlier compared to the neighboring ones (with an

Table 2

${ }^{14} \mathrm{C}$ age dating data (68\% range) determined for Unio crassus shells

\begin{tabular}{lllrrr}
\hline Sample & Depth $(\mathbf{c m})$ & Lab code & Years BP & Error & Cal yr BC \\
\hline KLM0 & 520 & GdA-557 & 21490 & 110 & $24015-23569$ \\
KLM2 & 475 & SUERC-36616 & 13975 & 45 & $15175-14957$ \\
KLM4 & 425 & SUERC-36617 & 14155 & 45 & $15315-15093$ \\
KLM6 & 375 & SUERC-36618 & 13335 & 45 & $14763-14332$ \\
KLM8 & 325 & SUERC-36619 & 12925 & 40 & $13663-13199$ \\
KLM10 & 275 & SUERC-36620 & 13740 & 45 & $14990-14829$ \\
KLM12 & 225 & deb-1069 & 11700 & 250 & $11851-11364$ \\
KLM15 & 150 & SUERC-36621 & 5905 & 40 & $4801-4724$ \\
KLM17 & 100 & Poz-23316 & 6890 & 40 & $5809-5726$ \\
KLM18 & 80 & SUERC-36625 & 5970 & 40 & $4857-4796$ \\
\hline
\end{tabular}




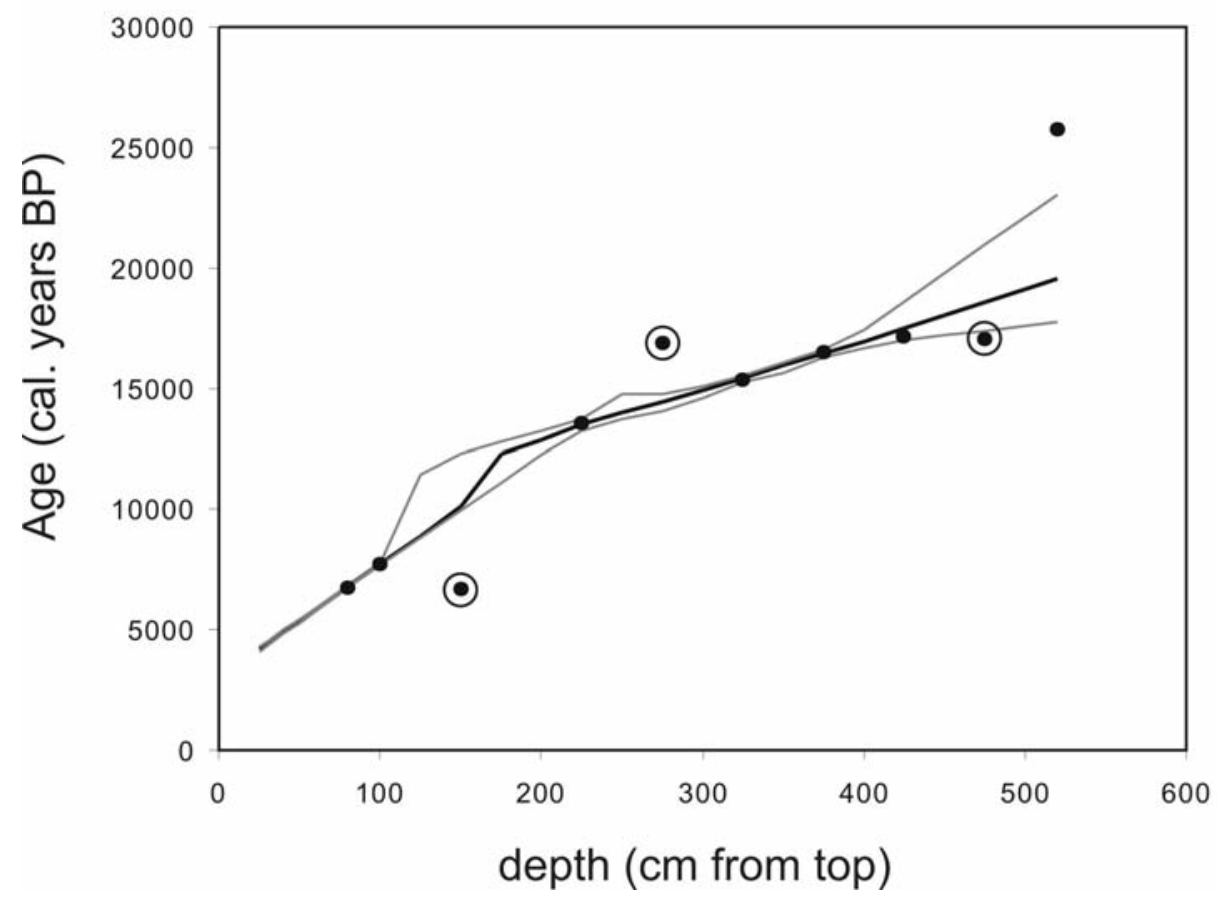

Fig. 2

Age-depth model (solid black line) with 95\% confidence limits (grey lines) for the Körösladány section based on the StalAge algorithm of Scholz and Hoffmann (2011). Samples excluded from the calculation (see text) are marked by empty circles

unexpectedly older age that may be related to re-sedimentation of shell fragments); hence these data were excluded from the age-depth model (see Fig. 2).

The mineralogical composition data are listed in Table 3. As usual for fluvial deposits, the studied sediments are dominated by quartz (54-68 wt.\%) and plagioclase (8-20 wt.\%), while phyllosilicates, feldspars, chlorite and carbonates are generally below $10 \mathrm{wt} . \%$. Between 300 and $375 \mathrm{~cm}$ the calcite content rises to $10-13 \mathrm{wt} . \%$ with a concomitant increase of dolomite to $5-9 \mathrm{wt} . \%$. The samples contained no aragonite. This is partly due to the collection of large shell fragments from the sediment samples. Below $400 \mathrm{~cm}$ (>17 ky cal BP), the carbonate amount is low with a relatively elevated calcite/dolomite ratio (expressed as Xcalcite in the bulk carbonate, Fig. 3A). Going up-section, the dolomite content suddenly increases at $375 \mathrm{~cm}(\sim 16.4 \mathrm{ky} \mathrm{BP})$, then shows a constant decrease along with the calcite/dolomite ratio (Fig. 3B).

Bulk sediment chemical compositions also display systematic variations (Table 4). The $\mathrm{SiO}_{2}$ content is slightly elevated (57 to 69 wt. \%) below $400 \mathrm{~cm}(\sim 17 \mathrm{ky} \mathrm{BP})$ 
Table 3

Mineralogical compositions (in wt.\%) of bulk sediment samples from the Körösladány section

\begin{tabular}{|c|c|c|c|c|c|c|c|}
\hline Depth $(\mathrm{cm})$ & $\mathrm{Qu}$ & $\mathrm{P} 1$ & $\mathrm{Kfp}$ & Shs & Chl & $\mathrm{Cc}$ & Dol \\
\hline 25 & 65 & 13 & 4 & 5 & 3 & 4 & 5 \\
\hline 50 & 67 & 9 & 6 & 5 & 4 & 4 & 6 \\
\hline 75 & 62 & 12 & 7 & 5 & 3 & 6 & 5 \\
\hline 100 & 64 & 12 & 3 & 6 & 3 & 6 & 5 \\
\hline 125 & 66 & 11 & 2 & 5 & 4 & 6 & 4 \\
\hline 150 & 63 & 13 & 4 & 5 & 4 & 7 & 5 \\
\hline 175 & 67 & 13 & 3 & 5 & 3 & 4 & 5 \\
\hline 200 & 55 & 20 & 4 & 5 & 3 & 7 & 7 \\
\hline 225 & 63 & 12 & 3 & 5 & 3 & 7 & 6 \\
\hline 250 & 61 & 14 & 4 & 5 & 3 & 9 & 5 \\
\hline 275 & 56 & 14 & 4 & 6 & 4 & 9 & 7 \\
\hline 300 & 54 & 13 & 5 & 5 & 3 & 13 & 8 \\
\hline 325 & 57 & 12 & 3 & 6 & 5 & 10 & 5 \\
\hline 350 & 58 & 10 & 3 & 4 & 3 & 13 & 9 \\
\hline 375 & 66 & 8 & 4 & 4 & 5 & 8 & 5 \\
\hline 400 & 68 & 14 & 2 & 5 & 3 & 6 & 1 \\
\hline 425 & 66 & 15 & 4 & 5 & 2 & 6 & 1 \\
\hline 450 & 67 & 15 & 4 & 5 & 3 & 5 & 1 \\
\hline 475 & 65 & 17 & 3 & 5 & 2 & 6 & 1 \\
\hline 500 & 62 & 13 & 3 & 5 & 4 & 11 & 2 \\
\hline
\end{tabular}

Qu: quartz, Pl: plagioclase, Kfp: K-feldspar, Shs: $10 \AA$ sheet silicates, Chl: chlorite, Cc: calcite, Dol: dolomite

compared to the upper section part (52 to 62 wt.\%) (Fig. 3C). The $\mathrm{MgO}$ concentration is low below $400 \mathrm{~cm}(1.7$ to $1.9 \mathrm{wt} . \%)$, suddenly increases to $3.4 \mathrm{wt} . \%$, then decreases gradually to about $2.4 \mathrm{wt} . \%$, with a significant positive MgOdolomite correlation $\left(\mathrm{R}^{2}=0.67\right)$. The $\mathrm{MnO}$ content shows again a difference between the lower $(\geq 400 \mathrm{~cm})$ and the upper part of the section $(0.18-0.38$ and $0.10-0.17$ wt. \%, respectively).

Chemical as well as stable carbon and oxygen isotope compositions of bulk sediment carbonate are listed in Table 4 . The oxygen isotope compositions are negatively correlated with the Sr content $\left(R^{2}=0.85\right)$ and show a well-expressed negative correlation $\left(\mathrm{R}^{2}=0.92\right)$ with the Xcalcite value (calcite/(calcite+dolomite) (Fig. 3D). The carbon isotope compositions of the bulk carbonate are negatively correlated with the carbonate content $\left(R^{2}=0.60\right)$, whereas the correlation with the Sr content is not that straightforward $\left(R^{2}=0.28\right)$. The carbon isotope - Xcalcite negative correlation is significant only if the samples below $400 \mathrm{~cm}$ are excluded $\left(R^{2}=0.70\right)$ (Fig. 3D). The concentrations of other mineral components and elements show either random or rather complex patterns.

$\mathrm{TiO}_{2}$ and $\mathrm{P}_{2} \mathrm{O}_{5}$ contents of bulk sediments are higher in the Holocene $(<10 \mathrm{ky})$ parts than in the Pleistocene layers (Fig. 4A) where they display similar patterns. The Sr concentration of the bulk sediment is 160 to $180 \mathrm{ppm}$ below $400 \mathrm{~cm}$, then decreases to about 120 ppm up-section (Fig. 4B).

The relationship between Xcalcite values and isotopic compositions of bulk carbonate determines the composition of the dolomite component with $\delta^{13} \mathrm{C} \sim$ $+3 \%$ and $\delta^{18} \mathrm{O} \sim-2 \%$. Using the Xcalcite and Xdolomite values measured by 

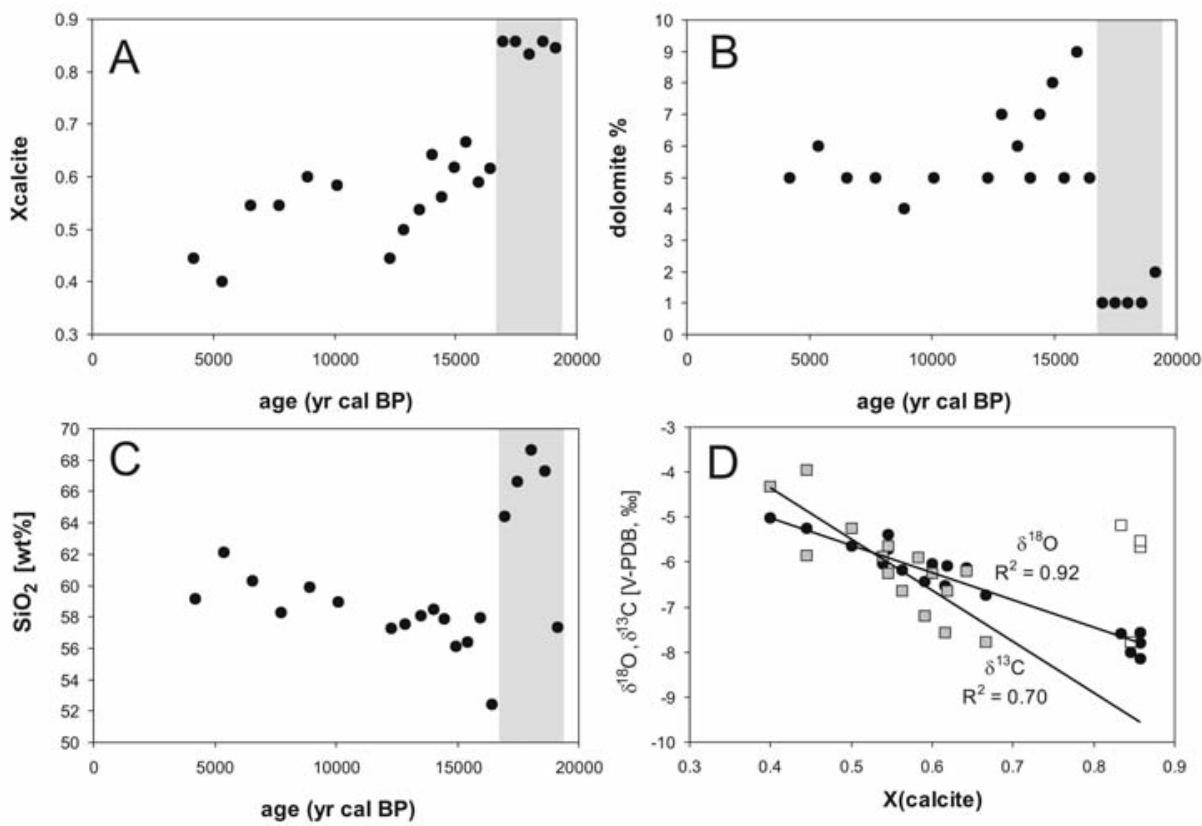

Fig. 3

Calcite content of the carbonate fraction (A) and dolomite (B) and $\mathrm{SiO}_{2}$ (C) contents of the bulk sediment of the Körösladány section as a function of age. (D) Stable carbon (squares) and oxygen (circles) isotope compositions of bulk carbonate vs. calcite content of the total carbonate fraction. Regression calculation was conducted for the carbon isotope compositions excluding the $>16.5 \mathrm{ky}$ samples due to the very different sedimentological characteristics of the section part (empty squares) (see text and Fig. 3A-C, grey shaded bars)

XRD analyses and the estimated dolomite compositions, $\delta^{13} \mathrm{C}$ and $\delta^{18} \mathrm{O}$ values can be calculated for the calcite component using the simple mass balance equation

$$
\delta \text { bulk }=\text { Xcalcite } \cdot \delta \text { calcite }+ \text { Xdolomite } \cdot \delta \text { dolomite }
$$

from which $\delta$ calcite $=(\delta$ bulk-Xdolomite $\cdot \delta$ dolomite $) /$ Xcalcite, where $\delta$ means $\delta^{13} \mathrm{C}$ and $\delta^{18} \mathrm{O}$ values.

The calculated $\delta^{18} \mathrm{O}$ values show a random fluctuation throughout the entire section (with an average of $-9.1 \pm 0.5 \%$ ), whereas the $\delta^{13} \mathrm{C}$ values display a distinct change from about $-7 \%$ (below $375 \mathrm{~cm}$ ) to $-13.5 \pm 1.4 \%$ obove this level (Fig. 4C-D). Interestingly, the calculated calcite $\delta^{13} \mathrm{C}$ and $\delta^{18} \mathrm{O}$ values are positively correlated with an $\mathrm{R}^{2}$ value of 0.75 in the upper part of the section.

The carbon isotope compositions of Unio crassus shells fluctuate between -14.0 and $-10.5 \%$, whereas their oxygen isotope values show a distinct pattern with $<-10 \%$ below $150 \mathrm{~cm}$ and a sudden increase to $-8.3 \%$ at $150 \mathrm{~cm}$ (Table 5, Fig. $4 \mathrm{C}-\mathrm{D})$. The $\delta^{13} \mathrm{C}$ and $\delta^{18} \mathrm{O}$ values of Sphaerium rivicola shells range from -11.4 to $-9.4 \%$ and from -11.3 to $-9.0 \%$, respectively (Table 5, Fig. 4C-D). Although the shells of the two bivalve species were collected from the same sediment samples 


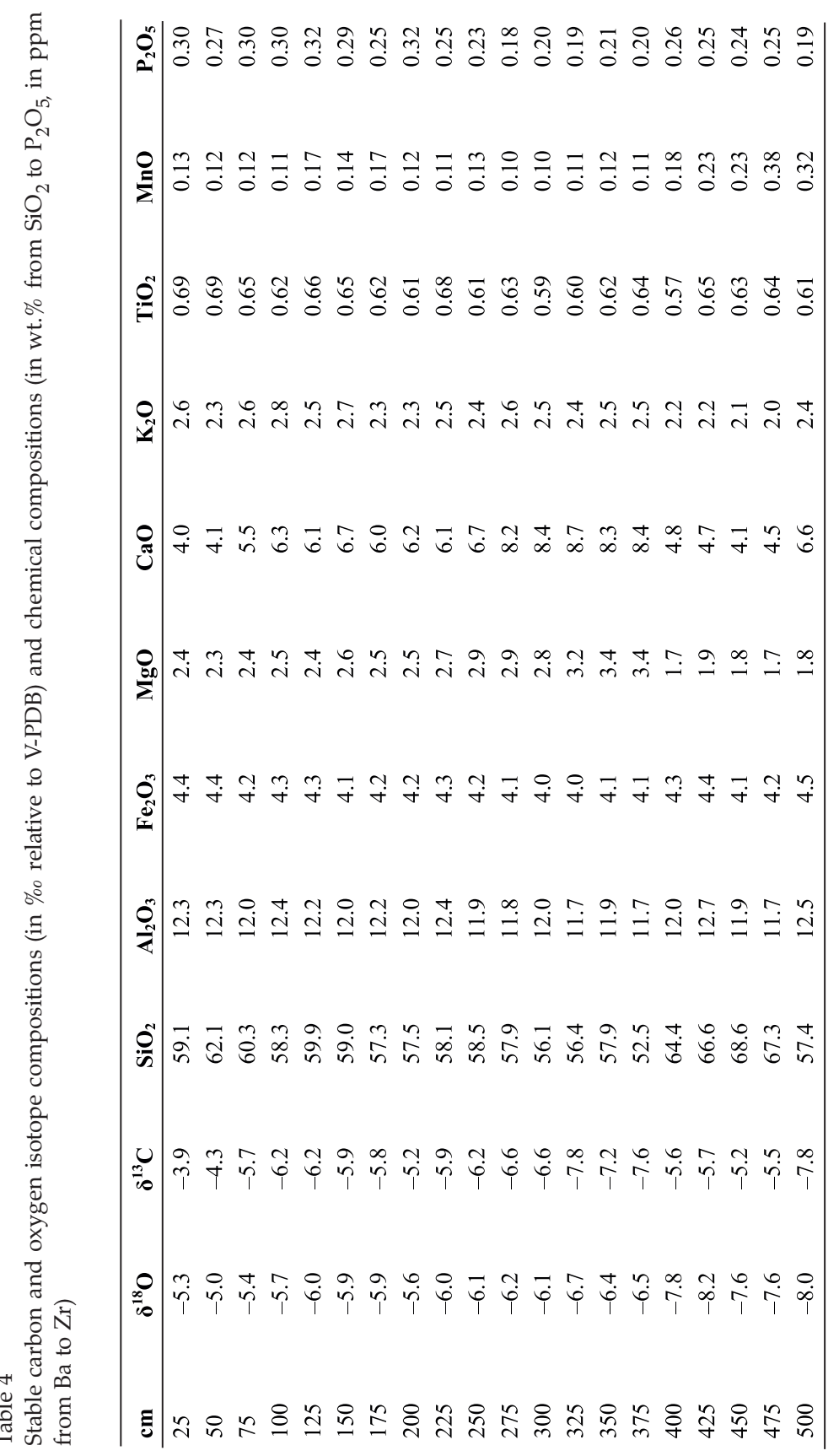


Stable isotope compositions of bivalve shells and geochemistry of bulk sediments at Körösladány 427

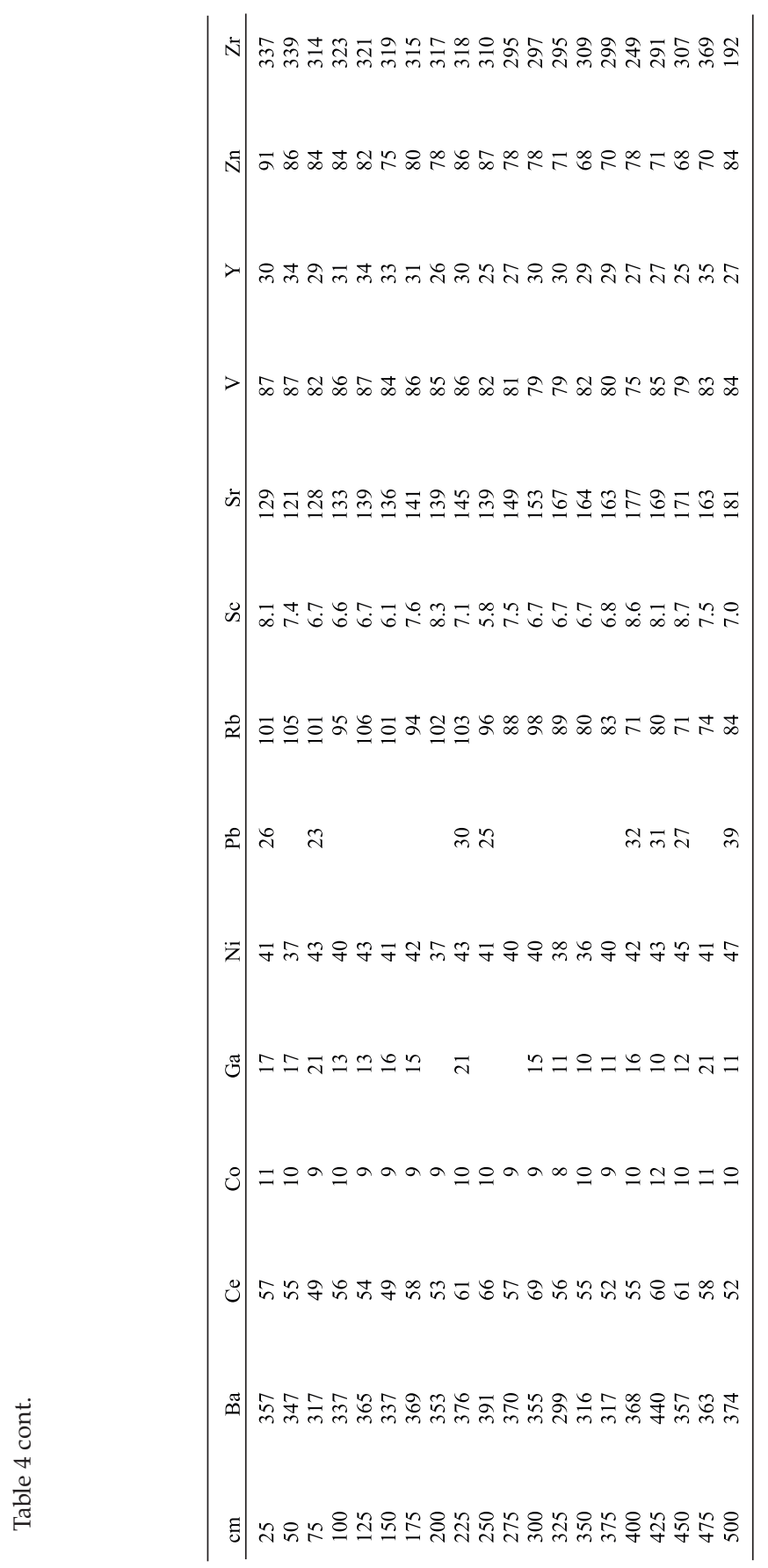

Central European Geology 55, 2012 

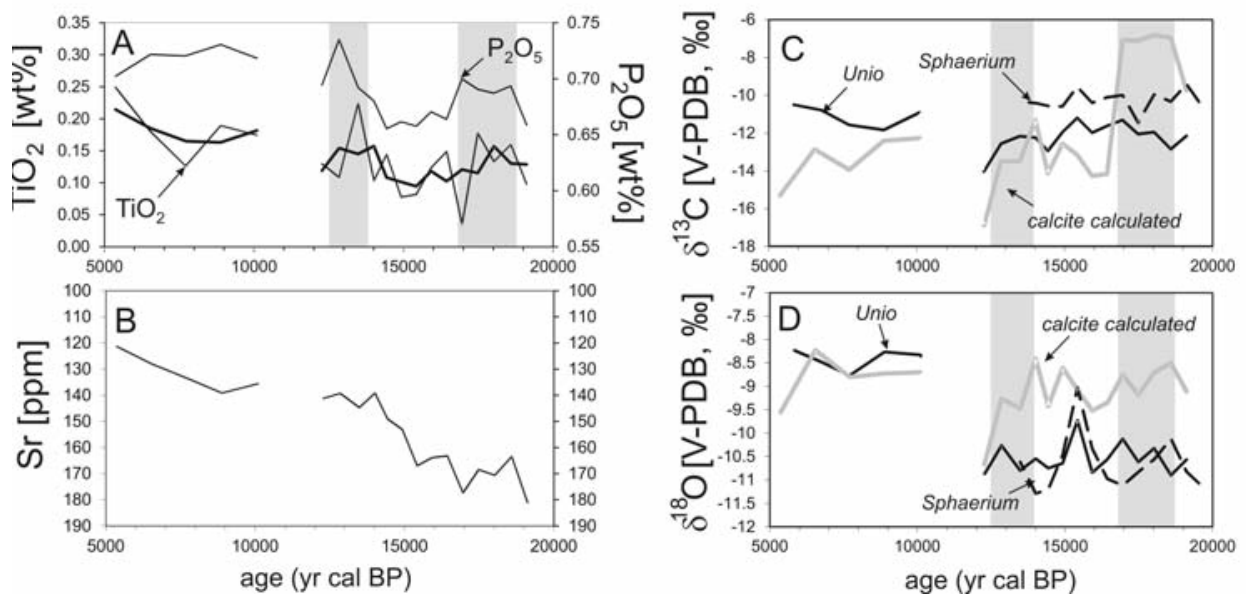

Fig. 4

(A) $\mathrm{TiO}_{2}$ (with 3-point running mean, thick solid line) and $\mathrm{P}_{2} \mathrm{O}_{5}$ contents, and (B) Sr contents of bulk sediment samples and stable carbon (C) and oxygen (D) isotope compositions of Unio crassus and Sphaerium rivicola shells as well as calculated compositions of the calcite fraction of bulk sediments (see text) as a function of age. Grey shaded bars denote Pleistocene periods with elevated $\mathrm{P}_{2} \mathrm{O}_{5}$ contents

from which bulk compositions were determined, no or very poor correlations $\left(R^{2}<0.22\right)$ have been observed between the different datasets.

\section{Discussions}

\section{Verification of the age-depth model}

An effective test for the reliability of the age-depth model obtained for the selected age dataset is based on comparison with well-dated records that may serve as references. Figure 5 shows a comparison between the isotopic compositions of Unio crassus shells, $\mathrm{P}_{2} \mathrm{O}_{5}$ contents of bulk sediment samples and, as references, the $\delta^{18} \mathrm{O}$ record of the GRIP ice core (Johnsen et al. 2001) and the $\delta^{13} \mathrm{C}$ data of a stalagmite from the Sofular Cave, Turkey (Fleitmann et al. 2009). The ice core record is traditionally used as a reference in paleoclimate studies, while the Sofular record represents an exceptionally well-dated stalagmite that will be used a regional reference. There are certain agreements and discrepancies in the patterns of the records. The Pleistocene-Holocene transition is visible in the rise of the shells' isotopic compositions as well as in the phosphorus contents. The sudden drop in these values around $12.3 \mathrm{ky}$ would be consistent with the Younger Dryas cooling (YD in Fig. 5), whereas the elevated phosphorus concentrations and the slight elevation in the $\delta^{13} \mathrm{C}$ (shell) values between 12.8 and $14.0 \mathrm{ky}$ compared to the samples just before and after these ages would agree with the Bølling/Allerød warm period. The older periods show discrepancies from the reference records that need to be discussed further (see later). However, the 


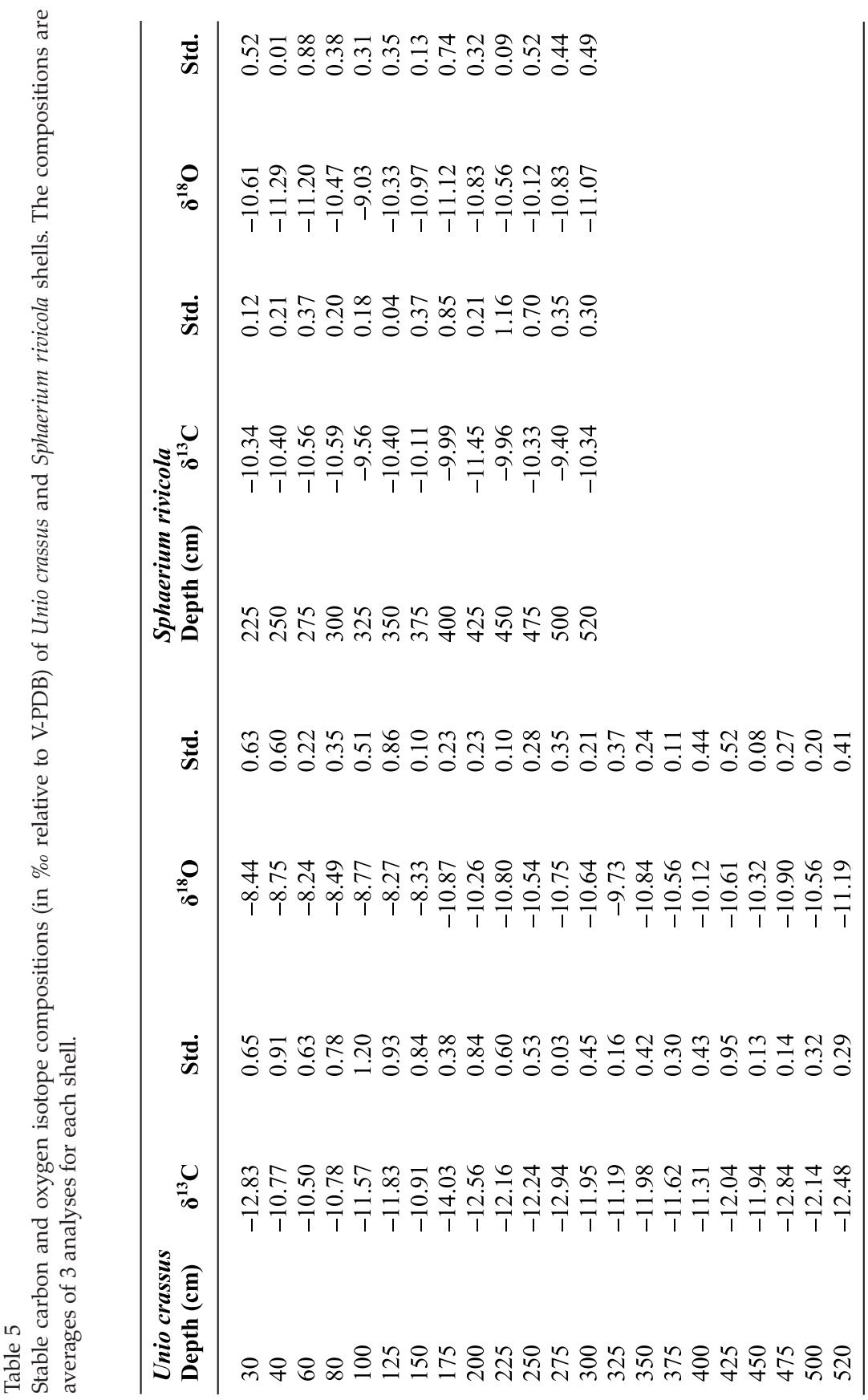



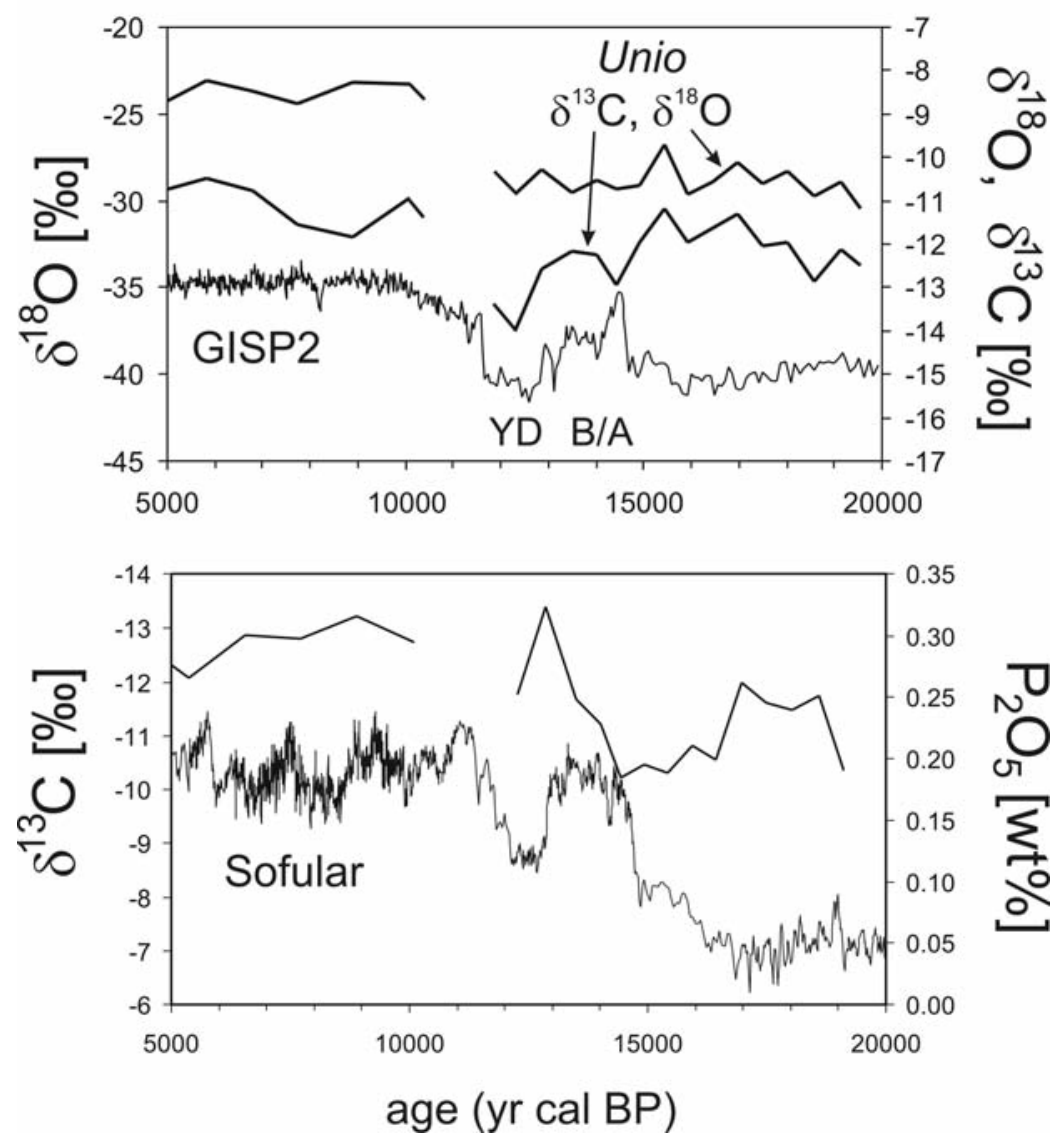

Fig. 5

Stable carbon and oxygen isotope compositions of Unio crassus shells, $\mathrm{P}_{2} \mathrm{O}_{5}$ contents of bulk sediments, stable oxygen isotope compositions of the GRIP ice core (Johnsen et al. 2001; relative to V-SMOW) and carbon isotope compositions of a stalagmite from the Sofular cave, Turkey (Fleitmann et al. 2009; (relative to V-PDB), respectively. YD: Younger Dryas, B/A: Bolling/Allerod

present comparison indicates that the age-depth model established for the Körösladány section is sufficiently precise for a more detailed discussion on paleoclimate conditions.

\section{Sedimentary changes}

Beside the temperature and humidity variations related to the climate change processes of the last $20 \mathrm{ky}$, the variations in mineralogical and chemical compositions indicate changes in depositional environment or denudation source as well. This assumption is supported by the observation that the bulk carbonate's 
isotopic compositions (which may depend on the amount and origin of detrital carbonate) show no relationships with the shell data (which may depend more on climate).

Between 16.5 and $19 \mathrm{ky}$ the composition of the sediment was different from that of the subsequent period, with a larger amount of $\mathrm{SiO}_{2}$, lower amount of dolomite, and calcite domination of the bulk carbonate (Fig. 3A-C). The good relationships between the bulk carbonate isotopic compositions and the mineralogical (e.g. calcite content in the bulk carbonate, see Fig. 3D) and chemical compositions (e.g. the negative correlation between bulk carbonate $\delta^{18} \mathrm{O}$ values and Sr contents with an $\mathrm{R}^{2}$ value of 0.85 ) suggest mixing of different components. These relationships show that denudation was dominated by siliceous and limestone-derived detrital material before $16.5 \mathrm{ky}$; thereafter a dolomitic terrain began to be eroded, later with some calcitic components in the sediments. The source area was most probably the Carpathian Mts., where the river originated. The good $\delta^{13} \mathrm{C}-\delta^{18} \mathrm{O}$ correlation in the calcite component and the constant decrease in the carbonate content along with the Xcalcite value may indicate mixing of different calcite types (detrital calcite from sedimentary rocks or from soils, authigenic calcite formed in the fluvial sediments, and secondary calcite formed by alteration of biogenic aragonite). The inferred mixing may explain the fluctuation in isotopic compositions of the calcite component; hence only the major Pleistocene-Holocene climate change may be reflected in them.

The observed change in sediment properties may be interpreted as a sign of variation in river pattern and erosion provenance. Reorganization of the fluvial system of the area took place in several steps during the Late Pleniglacial (Gábris and Nádor 2007; Kasse et al. 2010) due to climate-related variations in humidity. The chemical compositions are a consequence of different processes related to the late glacial climate changes. The bulk sediments' stable oxygen isotope compositions are positively correlated with the Sr contents and show a good correspondence with the global warming that started about $18 \mathrm{ky}$ ago (see the compilation of Shakun and Carlson 2010). The Sr content change can nicely be correlated with global signals like the $\delta^{18} \mathrm{O}$ rise (Blunier and Brook 2001) and the $\mathrm{CO}_{2}$ increase (Schmitt et al. 2012) in Antarctic ice cores, as well as records of regional significance such as the $\delta^{18} \mathrm{O}$ dataset of the Sofular cave stalagmite (Fleitmann et al. 2009) and the July mean temperature change in the Carpathians determined by Tóth et al. (2012). This indicates that carbonate denudation is related to temperature change that could have been responsible for the intensity of physical breakdown of limestone and dolomite. On the other hand, the $\mathrm{TiO}_{2}$ concentration in the bulk sediment shows a major increase during the Pleistocene-Holocene transition as well as during the Bølling/Allerød warm period (Fig. 4A). This pattern and the correspondence between the $\mathrm{TiO}_{2}$ and $\mathrm{P}_{2} \mathrm{O}_{5}$ changes indicate the effect of chemical weathering, the efficiency of which depends on temperature and humidity. A more humid climate is indicated by elevated phosphorus content in the fluvial sediment and the higher Ti contents 
in these periods were produced by increased chemical weathering. These observations show that the chemical composition of fluvial sediments can reflect both the long term-global temperature rise and the millennial scale temperature/ humidity changes.

\section{Climate-related changes}

The next question is whether climate-related isotopic variations can be detected in shells and bulk carbonates. As a usual reference the isotopic compositions are compared to the oxygen isotope record of the GRIP ice core (Fig. 5). The most obvious effect is related to the Pleistocene-Holocene change, which is appropriately reflected by the $\delta^{18} \mathrm{O}$ values of Unio shells (Fig. 5). The oxygen isotope composition of the calcite component of the bulk carbonate does not show a real change from the Pleistocene to the Holocene (Fig. 4D), which can be related to the mixing of different calcite components (detrital, authigenic and secondary calcite). The rather incoherent picture obtained from the isotopic compositions of bivalve shells in the Pleistocene can be related to the complex interplay of temperature of shell formation and water composition related to ambient air temperature and humidity (see the study of Schöll-Barna et al. 2012, on the Unio shells of Lake Balaton). A rather significant positive $\delta^{18} \mathrm{O}$ peak appears both in the Unio and the Sphaerium shells at about $15.5 \mathrm{ky}$ (Fig. 4C-D). This period just precedes the Bølling/Allerød warm period and can be attributed to the Oldest Dryas cold event (Alley and Clark 1999). Since these cold events (such as the Younger Dryas event; Magyari et al. 2012a) are also characterized by rather arid conditions, the strong evaporation under dry conditions could have been responsible for the coupled positive $\delta^{13} \mathrm{C}$ and $\delta^{18} \mathrm{O}$ shifts in the bivalve shells at about $15.5 \mathrm{ky}$. The assumed aridity is also supported by the low phosphorus content indicating decreased biogenic activity. Although this period was cold, temperature decrease would not serve as an explanation for the elevated $\delta^{18} \mathrm{O}$ values, as lower ambient temperatures would cause lower $\delta^{18} \mathrm{O}$ values in the precipitation water. Since the $\delta^{18} \mathrm{O}-\mathrm{T}$ gradient exceeds the effect of temperature decrease on the carbonate-water oxygen isotope fractionation (see Schöll-Barna et al. 2012), the net result of temperature decrease would be lower $\delta^{18} \mathrm{O}$ values in the carbonate.

The slightly elevated $\delta^{13} \mathrm{C}$ (shell) values and the increased phosphorus contents around 17-18 ky indicate another warm and humid period that is not represented in the ice core and stalagmite data described above. This period roughly corresponds to the Ságvár-Lascaux interstadial defined by Sümegi and Krolopp (2002). Since it may have been a local climate phenomenon, comparison with local paleoclimate data compilations could provide an insight into the significance of this event. Paleotemperature reconstructions spanning the entire period from the Last Glacial Maximum to the Holocene at sufficiently good age resolution are rather scarce (Sümegi and Krolopp 2002; Gábris and Nádor 2007). The bulk 
sediment $\mathrm{P}_{2} \mathrm{O}_{5}$ concentrations are compared with the paleotemperature data of Gábris and Nádor (2007) in Fig. 6, although we note that some of the data compiled by Gábris and Nádor (2007) are based on uncertain age dating. Again, the most prominent feature is the good correspondence between these records during the Pleistocene-Holocene transition and the Ságvár-Lascaux interstadial. Interestingly, the Ságvár-Lascaux interstadial seems to be more significant than the Bølling/Allerød period, both in the paleotemperature curve of Gábris and Nádor (2007) and in the malacothermometer data obtained for the southern part of the Great Hungarian Plain (Sümegi 2005), whereas the phosphorus concentrations are rather high in the younger period related to increased humidity compared to the Ságvár-Lascaux interstadial.

An attempt was made to compare the $\mathrm{C}$ and $\mathrm{O}$ isotope data of bivalve shells with the paleotemperature records of Sümegi (2005) and Gábris and Nádor (2007), but the comparison yielded an incomprehensible picture due to competing fractionation processes. The $\delta^{13} \mathrm{C}$ value of shell aragonite depends mainly on the carbon isotope composition of dissolved inorganic carbon (DIC) in the water and the amount of metabolic carbon incorporated by the shell (Dettman et al. 1999; Veinott and Cornett 1996; Lorrain et al. 2004; Gillikin et al. 2009). In a fluvial environment Zhou et al. (2010) detected C isotope changes in the DIC related to biogenic activity, with DIC enriched in ${ }^{13} \mathrm{C}$ in highly eutrophic water bodies due

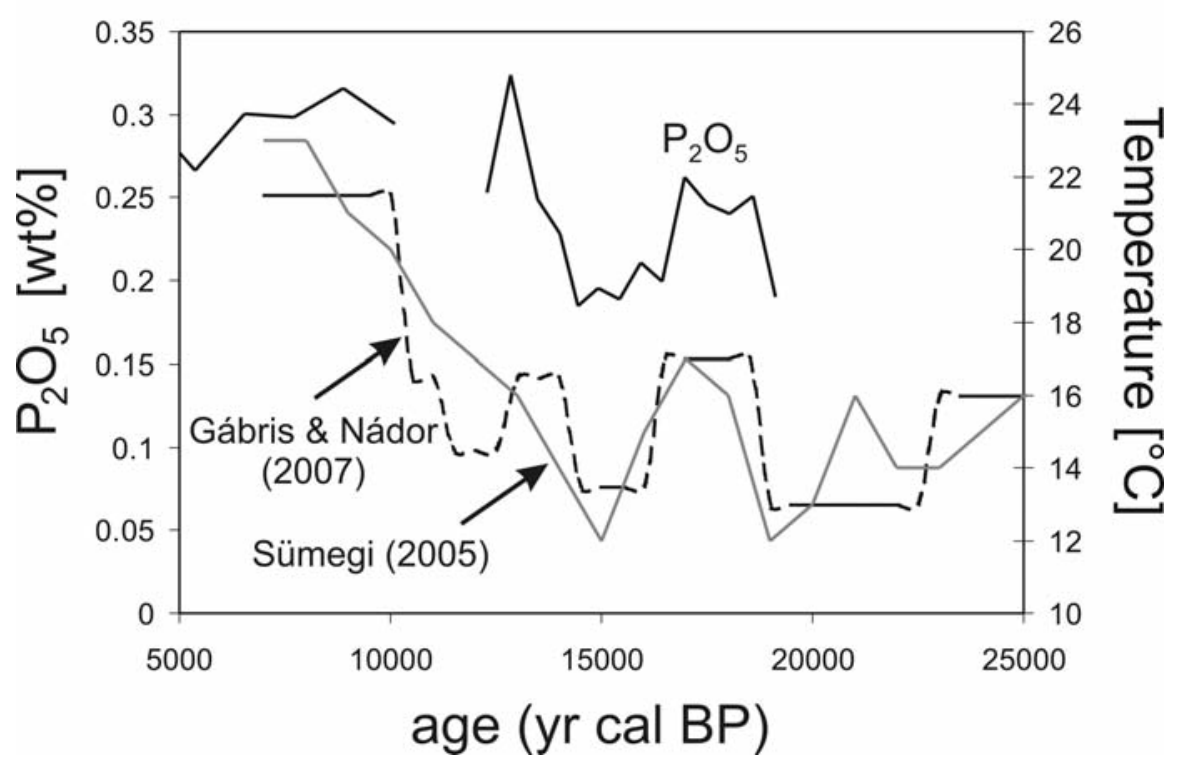

Fig. 6

Comparison of $\mathrm{P}_{2} \mathrm{O}_{5}$ contents of bulk sediments of the Körösladány section and paleotemperature data of Sümegi (2005) and Gábris and Nádor (2007) 
to the ${ }^{12} \mathrm{C}$-removal by the organic matter. The $\delta^{18} \mathrm{O}$ value of shell aragonite depends on the ambient temperature and the oxygen isotope composition of the water (Grossman and Ku 1986; Dettman et al. 1999). Water composition can be calculated from the measured shell $\delta^{18} \mathrm{O}$ values using the paleotemperature data of Gábris and Nádor (2007) and the shell-water fractionation equation of Dettman et al. (1999). If the temperature variations are preserved in the $\delta^{18} \mathrm{O}$ (shell) values, realistic water composition should be obtained. In theory, at constant water composition the changes in $\delta^{18} \mathrm{O}$ value of shells would be determined entirely by temperature variations. On the other hand, calculation of water composition would eliminate the temperature effect, and fluctuations in the water value would be related to paleohydrological changes. The calculated water composition ranged from -12.7 to $-8.0 \%$ (Fig. 7), in good agreement with published values (from -14 to $-8 \%$; Varsányi et al. 2011). For precipitation water there is a well-known relationship between the water's oxygen isotope composition and the ambient temperature that depends on the local climate conditions. The $\delta^{18} \mathrm{O} / \Delta \mathrm{T}$ coefficient is 0.37 for the Great Plain (Deák 1995 cited in Fórizs 2003; Vodila et al. 2011), whereas the slope of the relationship is higher for the precipitation in the Carpathians (Kern et al. 2009) from where most of the Tisza waters originate. Plotting the calculated water composition against paleotemperature revealed a relatively elevated $\Delta^{18} \mathrm{O} / \Delta \mathrm{T}$ coefficient above $16{ }^{\circ} \mathrm{C}$ and quasi constant $\delta^{18} \mathrm{O}$ (water) values below $16{ }^{\circ} \mathrm{C}$ (Fig. 7), raising the possibility of a changing $\Delta^{18} \mathrm{O}-\Delta \mathrm{T}$

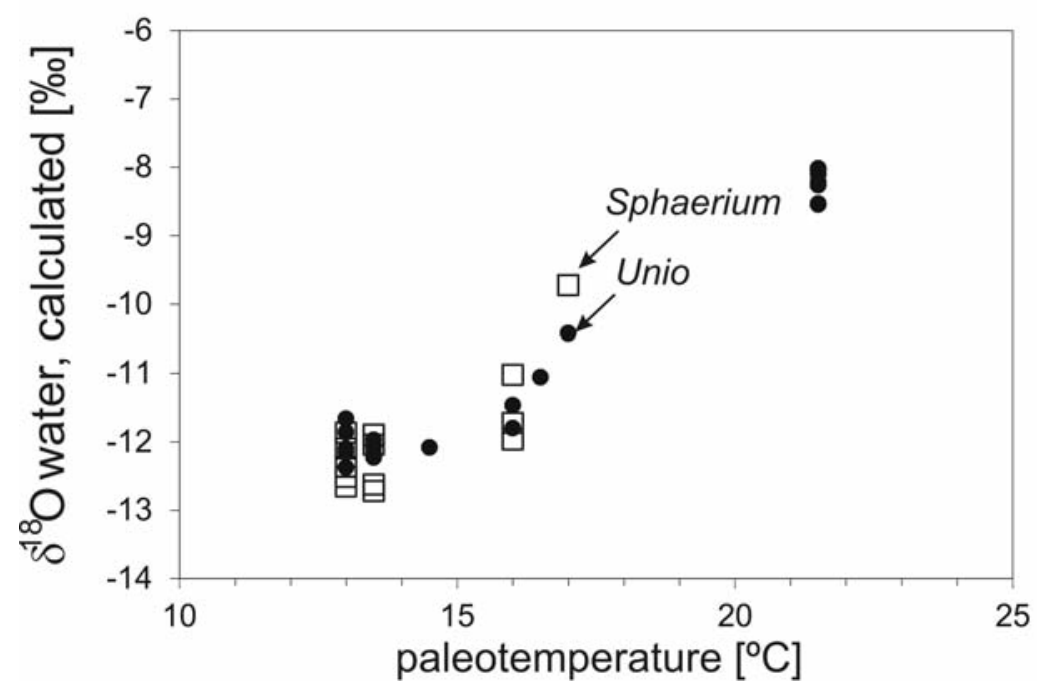

Fig. 7

Calculated water compositions (relative to V-SMOW) (from the data of Unio and Sphaerium shells, respectively, see text) as a function of paleotemperature data of Gábris and Nádor (2007) 
equation. The observed changes indicate that a strong $\Delta^{18} \mathrm{O}-\Delta \mathrm{T}$ relationship existed for the warm periods (the Holocene, the Bølling/Allerød and the SágvárLascaux interstadials), whereas the $\delta^{18} \mathrm{O}$ (water) values showed no significant change with temperature during the cold periods. This can be explained by assuming a buffer of massive snow cover in the Carpathians during the cold periods, whose summer melting produced a continuous input of ${ }^{18} \mathrm{O}$-depleted precipitation, providing a buffer for the $\mathrm{O}$ isotope composition of the Tisza river during the cold periods. On the other hand, at periods above $16{ }^{\circ} \mathrm{C}$ mean summer temperature, the calculated water composition shows a strong dependence on ambient temperature, similar to meteoric waters in the Carpathian Mountains. Interestingly, the data belonging to the Ságvár-Lascaux interstadial also indicate an elevated $\Delta^{18} \mathrm{O}-\Delta \mathrm{T}$ relationship, which means a significant reduction in the summer snow cover in the Carpathians.

\section{Conclusions}

A $5.2 \mathrm{~m}$-thick fluvial sequence in southeastern Hungary was studied by means of mineralogical, geochemical and stable $\mathrm{C}$ and $\mathrm{O}$ isotope analyses of bulk sediments as well as stable $\mathrm{C}$ and $\mathrm{O}$ isotope analyses of Unio crassus and Sphaerium rivicola shells. On the basis of ${ }^{14} \mathrm{C}$ age dating, the section covers the period of about 5-20 ky BP. Effects of sedimentary changes could be detected in the chemical and isotopic compositions of fluvial sediments. The chemical composition of the bulk sediments indicated changes in denudation style from physical erosion of carbonate rocks (affecting bulk carbonate isotope compositions and bulk sediment $\mathrm{Sr}$ concentrations) due to a long-term temperature rise during the latest glacial, to chemical weathering of silicate rocks (determining the Ti concentrations) attributed to humidity increase indicated by an elevated phosphorus content of bulk sediment samples. Comparing the data with local paleotemperature reconstructions, it was concluded that the $\mathrm{C}$ and $\mathrm{O}$ isotope compositions of Unio and Sphaerium shells reflect climate conditions. Beside the globally important Bølling/Allerød and Younger Dryas periods, the locally significant Ságvár-Lascaux interstadial appears significant in the isotopic and chemical records. Calculated $\Delta^{18} \mathrm{O}-\Delta \mathrm{T}$ relationships indicate that during the cold periods the snow cover in the Carpathian Mts. served as a low $-\delta^{18} \mathrm{O}$ buffer for the river water, whereas warmer periods (including the Ságvár-Lascaux interstadial) were associated with strong reduction of summer snow cover.

\section{Acknowledgements}

This study was financially supported by the Hungarian Scientific Research Fund (OTKA K-68343). The authors are deeply indebted for the constructive reviews provided by Dr. Karina Apolinarska and Dr. János Kovács. 


\section{References}

Alley, R.B., P.U. Clark 1999: The deglaciation of the northern hemisphere: a global perspective. Annual Reviews of Earth and Planetary Sciences, 27, pp. 149-182.

Blunier, T., E.J. Brook 2001: Timing of millennial-scale climate change in Antarctica and Greenland during the last glacial period. - Science, 291, pp. 109-112.

Bond, G.C., W. Shower, M. Elliot, M. Evans, R. Lotti, I. Hajdas, G. Bonani, S. Johnson 1999: The North Atlantic's 1-2 kyr Climate Rhythm: Relation to Heinrich Events, Dansgaard/Oeschger Cyles and the Little Ice Age. In: Clark, P.U., R.S. Webb, L.D. (Eds): KeigwinMechanisms of Global Climate Change at Millennial Time Scales. - Geophysical Monograph, 112, pp. 35-58, American Geophysical Union.

Bond, G., B. Kromer, J. Beer, R. Muscheler, M.N. Evans, W. Showers, S. Hoffmann, R. Lotti-Bond, I. Hajdas, G. Bonani 2001: Persistent solar influence on North Atlantic climate during the Holocene. - Science, 294, pp. 2130-2136.

Bridge, J.S. 1993: Description and interpretation of fluvial deposits: a critical perspective. Sedimentology, 40, pp. 801-810.

Buczkó, K., E. Magyari, T. Hübener, M. Braun, M. Bálint, E. Tóth, A.F. Lotter 2012: Responses of diatoms to the Younger Dryas climatic reversal in a South Carpathian mountain lake (Romania). - Journal of Paleolimnology, 48, pp. 417-431.

Demény, A., Gy. Czuppon, Z. Siklósy, Sz. Leél-Őssy, K. Lin, C.-C. Shen, K. Gulyás 2012: Mid-Holocene climate conditions and moisture source variations based on stable $\mathrm{H}, \mathrm{C}$ and $\mathrm{O}$ isotope compositions of speleothems in Hungary. - Quaternary International (in press)

Denton, G.H., R.F. Anderson, J.R. Toggweiler, R.L. Edwards, J.M. Schaefer, A.E. Putnam 2010: The last glacial Termination. - Science, 328, pp. 1652-1656.

Dettman, D.L., A.K. Reische, K.C. Lohmann 1999: Controls on the stable isotope composition of seasonal growth bands in aragonitic fresh-water bivalves (Unionidae). - Geochimica et Cosmochimica Acta, 63, pp. 1049-1057.

EPICA Community Members 2004: Eight glacial cycles from an Antarctic ice core. - Nature, 429, pp. 623-628.

Feurdean, A., S. Klotz, V. Mosbrugger, B. Wohlfarth 2008: Pollen-based quantitative reconstruction of Holocene climate variability in NW Romania. - Palaeogeography, Palaeoclimatology, Palaeoecology, 260, pp. 494-504.

Fleitmann, D., H. Cheng, S. Badertscher, R.L. Edwards, M. Mudelsee, O.M. Göktürk, A. Fankhauser, R. Pickering, C.C. Raible, A. Matter, J. Kramers, O. Tüysüz 2009: Timing and climatic impact of Greenland interstadials recorded in stalagmites from northern Turkey. - Geophysical Research Letters, 36, L19707.

Fórizs, I. 2003: Isotopes as natural tracers in the water cycle: Examples from the Carpathian Basin. Studia Universitatis Babes-Bolyai, Physica, Special Issue XLVIII (vol. 1), pp. 69-77.

Freeman, S.P.H.T., G.T. Cook, A.B. Dougans, P. Naysmith, K.M. Wilcken, S. Xu 2010: Improved SSAMS performance. - Nuclear Instruments and Methods, B 268, pp. 715-717.

Gábris, Gy., A. Nádor 2007: Long-term fluvial archives in Hungary: response of the Danube and Tisza rivers to tectonic movements and climatic changes during the Quaternary: a review and new synthesis. - Quaternary Science Reviews, 26, pp. 2758-2782.

Gillikin, D.P., K.A. Hutchinson, Y. Kumai 2009: Ontogenic increase of metabolic carbon in freshwater mussel shells (Pyganodon cataracta). - Journal of Geophysical Research, 114, G01007.

Grossman, E.L., T.L. Ku 1986: Oxygen and carbon isotope fractionation in biogenic aragonite: temperature effects. - Chemical Geolology (Isotope Geoscience Section), 59, pp. 59-74.

Hertelendi, E., É. Csongor, L. Záborszky, I. Molnár, I. Gál, M. Győrffy, S. Nagy 1989: Counting system for high precision C-dating. - Radiocarbon, 32, pp. 399-408

Hertelendi, E., P. Sümegi, Gy. Szöőr 1992: Geochronologic and palaeoclimatic characterization of quaternary sediments in the great Hungarian plain. - Radiocarbon, 34, pp. 833-839. 
Hurrell, J.W., C. Deser 2010: North Atlantic climate variability: The role of the North Atlantic Oscillation. - Journal of Marine Systems, 79, pp. 231-244.

Imbrie, J., J.D. Hays, D.G. Martinson, A. McIntyre, A.C. Mix, J.J. Morley, N.G. Paces, W.L. Prell, N.J. Shackleton 1984: The orbital theory of Pleistocene climate: Support from a revised chronology of the marine $\delta^{18} \mathrm{O}$ record. - In: Berger, A.L., J. Imbrie, J. Hays, G. Kukla, B. Saltzman (Eds): Milankovitch and Climate, Part 1. D. Reidel, Reidel, pp. 269-305.

Jenei, M., S. Gulyás, P. Sümegi, M. Molnár 2007: Holocene lacustrine carbonate formation: old ideas in the light of new radiocarbon data from a single site in Central Hungary. - Radiocarbon, 49, pp. 1017-1021.

Johnsen, S.J., D. Dahl-Jensen, N. Gundestrup, J.P. Steffensen, H.B. Clausen, H. Miller, V. MassonDelmotte, A.E. Sveinbjörnsdottir, J. White 2001: Oxygen isotope and palaeotemperature records from six Greenland ice-core stations: Camp Century, Dye-3, GRIP, GISP2, Renland and NorthGRIP. - Journal of Quaternary Science, 16, pp. 299-307.

Kasse, C., S.J.P. Bohncke, J. Vandenberghe, Gy. Gábris 2010: Fluvial style changes during the last glacial-interglacial transition in the middle Tisza valley (Hungary). - Proceedings of the Geologists' Association, 121, pp. 180-194.

Kern, Z., I. Fórizs, A. Persoiu, B. Nagy 2009: Stable isotope study of water sources and of an ice core from the Bortig Ice Cave, Romania. - Data of Glaciological Studies (Materialy Glyatsiologicheskikh Issledovaniy), 107, pp. 175-182.

Kovács, J., M. Moravcová, G. Újvári, A.G. Pintér 2012: Reconstructing the paleoenvironment of East Central Europe in the Late Pleistocene using the oxygen and carbon isotopic signal of tooth in large mammal remains. - Quaternary International, 276-277, pp. 145-154.

Lorrain, A., Y.-M. Paulet, L. Chauvaud, R. Dunbar, D. Mucciarone, M. Fontugne 2004: $\delta^{13} \mathrm{C}$ variation in scallop shells: Increasing metabolic carbon contribution with body size? - Geochimica et Cosmochimica Acta, 68, pp. 3509-3519.

Magyari, E., K. Buczkó, G. Jakab, M. Braun, Z. Pál, D. Karátson, I. Pap 2009: Palaeolimnology of the last crater lake in the Eastern Carpathian Mountains: a multiproxy study of Holocene hydrological changes. - Hydrobiologia, 631, pp. 29-63.

Magyari, E.K., G. Jakab, M. Bálint, Z. Kern, K. Buczkó, M. Braun 2012a: Rapid vegetation response to Lateglacial and early Holocene climatic fluctuation in the South Carpathian Mountains (Romania). - Quaternary Science Reviews, 35, pp. 116-130.

Magyari, E.K., A. Demény, K. Buczkó, Z. Kern, T. Vennemann, I. Fórizs, I. Vincze, M. Braun, J.I. Kovács, B. Udvardi, D. Veres 2012b: A 13,600-year diatom oxygen isotope record from the South Carpathians (Romania): Reflection of winter conditions and possible links with North Atlantic circulation changes. - Quaternary International (in press)

McCrea, J.M. 1950: On the isotope chemistry of carbonates and a paleotemperature scale. - The Journal of Chemical Physics, 18, pp. 849-857.

Morley, A., M. Schulz, Y. Rosenthal, S. Mulitza, A. Paul, C. Rühlemann 2011: Solar modulation of North Atlantic central Water formation at multidecadal timescales during the late Holocene. Earth and Planetary Science Letters, 308, pp. 161-171.

Novothny, Á., M. Frechen, E. Horváth, B. Bradák, E.A. Oches, W. McCoy, T. Stevens 2009: Luminescence and amino acid racemization chronology and magnetic susceptibility record of the loess-paleosol sequence at Süttő, Hungary. - Quaternary International, 198, pp. 62-76.

Novothny, Á., M. Frechen, E. Horváth, L. Wacha, C. Rolf 2011: Investigating the penultimate and last glacial cycles of the Süttő loess section (Hungary) using luminescence dating, high-resolution grain size, and magnetic susceptibility data. - Quaternary International, 234, pp. 75-85.

Paillard, D. 2001: Glacial cycles: toward a new paradygm. - Reviews of Geophysics, 39, pp. 325-346.

Petit, J.R., J. Jouzel, D. Raynaud, N.I. Barkov, J.-M. Barnola, I. Basile, M. Bender, J. Chapellaz, M. Davis, G. Delayque, M. Delmotte, V.M. Kotlyakov, M. Legrand, V.Y. Lipenkov, C. Lorius, L. Pépin, C. Ritz, E. Saltzmann, M. Stievenard 1999: Climate and atmospheric history of the past 420,000 years from the Vostok ice core, Antarctica. - Nature, 399, pp. 429-436. 
Schatz, A.-K., M. Zech, B. Buggle, S. Gulyás, U. Hambach, S.B. Markovic, P. Sümegi, T. Scholten 2011: The late Quaternary loess record of Tokaj, Hungary: reconstructing palaeoenvironment, vegetation and climate using stable $\mathrm{C}$ and $\mathrm{N}$ isotopes and biomarkers. - Quaternary International, 240, pp. 52-61.

Schatz, A.-K., J.-P. Buylaert, A. Murray, T. Stevens, T. Scholten 2012: Establishing a luminescence chronology for a palaeosol-loess profile at Tokaj (Hungary): A comparison of quartz OSL and polymineral IRSL signals. - Quaternary Geochronology, 10, pp. 8-74.

Schmitt, J., R. Schneider, J. Elsig, D. Leuenberger, A. Lourantou, J. Chappellaz, P. Köhler, F. Joos, TF. Stocker, M. Leuenberger, $\mathrm{H}$. Fischer 2012: Carbon isotope constraints on the deglacial $\mathrm{CO}_{2}$ rise from ice cores. - Science, 336, pp. 711-714.

Scholz, D., D.L. Hoffman 2011: StalAge e an algorithm designed for construction of speleothem age models. - Quaternary Geochronology, 6, pp. 369-382.

Schöll-Barna, G., A. Demény, G. Serlegi, Sz. Fábián, P. Sümegi, F. Fórizs, B. Bajnóczi 2012: Climatic variability in the Late Copper Age: Stable isotope fluctuation of prehistoric Unio pictorum (Unionidae) shells from Lake Balaton (Hungary). - Journal of Paleolimnology, 47, pp. 87-100.

Schulz, K.G., R.E. Zeebe 2006: Pleistocene glacial terminations triggered by synchronous changes in Southern and Northern Hemisphere insolation: The insolation canon hypothesis. - Earth and Planetary Science Letters, 249, pp. 326-336.

Shakun, J.D., A.E. Carlson 2010: A global perspective on last glacial maximum to Holocene climate change. - Quaternary Science Reviews, 29, pp. 1801-1816.

Shi, C., R. Zhu, B.P. Glass, Q. Liu, A. Zeman, V. Suchy 2003: Climate variations since the last interglacial recorded in Czech loess. - Geophysical Research Letters, 30, 1562. doi:10.1029/2003GL017251, 11.

Siklósy, Z., A. Demény, Sz. Leél-Őssy, I. Szenthe, S.E. Lauritzen, C.-C. Shen 2011: A cseppkövek kormeghatározása és azok paleoklimatológiai jelentósége (The dating of stalagmites and their palaeoclimatological significance). - Földtani Közlöny, 141, pp. 73-87.

Spötl, C., T.W. Wennemann 2003: Continuous-flow isotope ratio mass spectrometric analysis of carbonate minerals. - Rapid Communications in Mass Spectrometry, 17, pp. 1004-1006.

Stevens, T., S.B. Markovic, M. Zech, U. Hambach, P. Sümegi 2011: Dust deposition and climate in the Carpathian Basin over an independently dated last glaciale-interglacial cycle. - Quaternary Science Reviews, 30, pp. 662-681.

Sümegi, P. 2005: Loess and the Upper Paleolithic Environment in Hungary: An Introduction to the Environmental History of Hungary. - Aurea Kiadó, Nagykovácsi, 312 pp.

Sümegi, P., E. Hertelendi 1998: Reconstruction of microenvironmental changes in the Kopasz Hill loess area at Tokaj (Hungary) between 15 and 70 ka BP. - Radiocarbon, 40, pp. 855-863.

Sümegi, P., E. Krolopp 2002: Quatermalacological analyses for modeling of the Upper Weichselian palaeoenvironmental changes in the Carpathian Basin. - Quaternary International, 91, pp. 53-63.

Sümegi, P., Z.E. Rudner 2001: In situ charcoal fragments as remains of natural wild fires in the upper Würm of the Carpathian Basin. - Quaternary International, 76-77, pp. 165-176.

Sümegi, P., S. Gulyás, G. Persaits, D.G. Páll, D. Molnár 2011a: The loess-paleosol sequence of Basaharc (Hungary) revisited: Mollusc-based paleoecological results for the Middle and Upper Pleistocene. - Quaternary International, 240, pp. 181-192.

Sümegi, P., M. Molnár, G. Jakab, G. Persaits, P. Majkut, D.G. Páll, S. Gulyás, A.J.T. Jull, T. Törcsik 2011b: Radiocarbon-dated paleoenvironmental changes on a lake and peat sediment sequence from the Central Great Hungarian Plane (Central Europe) during the last 25,000 years. Radiocarbon, 53, pp. 85-97.

Tóth, M., E. Magyari, S.J. Brooks, M. Braun, K. Buczkó, M. Bálint, O. Heiri 2012: A chironomid-based reconstruction of late glacial summer temperatures in the southern Carpathians (Romania). Quaternary Research, 77, pp. 122-131.

Troels-Smith, J. 1955: Karakterisering af lose jordater. - Danmarks Geologiske Undersogelse, ser. IV. (10). 
Tullner, T., T. Cserny 2003: New aspects of lake-level changes, Lake Balaton, Hungary. - Acta Geologica Hungarica, 46, pp. 215-238.

Varsányi, I., L. Palcsu, L. Ó. Kovács 2011: Groundwater flow system as an archive of palaeotemperature: Noble gas, radiocarbon, stable isotope and geochemical study in the Pannonian Basin, Hungary. - Applied Geochemistry, 26, pp. 91-104.

Veinott, G.I., R.J. Cornett 1996: Identification of annually produced opaque bands in the shell of the freshwater mussel Elliptio complanata using the seasonal cycle of $\delta^{18} \mathrm{O}$. - Canadian Journal of Fisheries and Aquatic Sciences, 53, pp. 372-379.

Vendel, M. 1959: The methods of the Rock Identification. - Akadémiai Kiadó, Budapest, p. 754. (In Hungarian.)

Versteegh, G.J.M. 2005: Solar forcing of climate 2: evidence from the past. - Space Science Reviews, 120, pp. 243-286

Vodila, G., L. Palcsu, I. Futó, Zs. Szántó 2011: A 9-year record of stable isotope ratios of precipitation in Eastern Hungary: Implications on isotope hydrology and regional palaeoclimatology. Journal of Hydrology, 400, pp. 144-153.

Zhou, H., C.Q. Liu, Q. Jiang, W. Jiang, Y.L. Zhao, W.C. Ding, H. Yan 2010: Stable carbon isotopes in the shell of Corbicula fluminea (Muller 1774): Implications for understanding environmental changes in drainage basins. - Chinese Science Bulletin, 55, pp. 4162-4167. 